\title{
Rootstocks induce contrasting photosynthetic responses of orange plants to low night temperature without affecting the antioxidant metabolism
}

\author{
Daniela Favero São Pedro Machado' ${ }^{1}$ Rafael Vasconcelos Ribeiro², Joaquim Albenísio \\ Gomes da Silveira ${ }^{3}$, José Rodrigues Magalhães Filho', Eduardo Caruso Machado'*
}

'Laboratory of Plant Physiology "Coaracy M. Franco", Instituto de Agronomia (IAC), Campinas, SP, Brazil.

2Plant Biology Department, Instituto de Biologia, Universidade Estadual de Campinas (UNICAMP), Campinas, SP, Brazil.

${ }^{3}$ Biochemistry and Molecular Biology Department, Universidade Federal do Ceará (UFC), Fortaleza, CE, Brazil.

*Corresponding author: caruso@iac.sp.gov.br

Received: March 12, 2013; Accepted: April 16, 2013

ABSTRACT: Low temperatures negatively impact the metabolism of orange trees, and the extent of damage can be influenced by the rootstock. We evaluated the effects of low nocturnal temperatures on Valencia orange scions grafted on Rangpur lime or Swingle citrumelo rootstocks. We exposed six-month-old plants to night temperatures of $20^{\circ} \mathrm{C}$ and $8^{\circ} \mathrm{C}$ under controlled conditions. After decreasing the temperature to $8^{\circ} \mathrm{C}$, there were decreases in leaf $\mathrm{CO}_{2}$ assimilation, stomatal conductance, mesophyll conductance and $\mathrm{CO}_{2}$ concentration in the chloroplasts, in plant hydraulic conductivity and in the maximum electron transport rate driven ribulose-1,5bisphosphate (RuBP) regeneration in plants grafted on both rootstocks. However, the effects of low night temperature were more severe in plants grafted on Rangpur rootstock, which also presented reduction in the maximum rate of RuBP carboxylation and in the maximum quantum efficiency of the PSII. In general, irreversible damage due to night chilling was found in the photosynthetic apparatus of plants grafted on Rangpur lime. Low night temperatures induced similar changes in the antioxidant metabolism, preventing oxidative damage in citrus leaves on both rootstocks. As photosynthesis is linked to plant growth, our findings indicate that the rootstock may improve the performance of citrus trees in environments with low night temperatures, with Swingle rootstock improving the photosynthetic acclimation in leaves of orange plants.

KEYWORDS: Citrus sinensis, chlorophyll fluorescence, gas exchange, chilling, antioxidant metabolism.

\section{INTRODUCTION}

Under subtropical conditions, $\mathrm{CO}_{2}$ assimilation $\left(P_{\mathrm{n}}\right)$ is significantly lower during the winter as compared to the spring and summer seasons (Machado et al. 2002, Ribeiro and Machado 2007, Ribeiro et al. 2009a, 2009b). Reduced photosynthetic activity has been associated with low night temperatures during the winter season (Machado et al. 2002, Ribeiro et al. 2009a, 2009b). Machado et al. (2010) found decreased $P_{n}$, stomatal conductance $\left(g_{s}\right)$, PSII operational efficiency and an increase in the ratio between electron transport and $\mathrm{CO}_{2}$ assimilation due to cold night. Low soil temperatures also reduce photosynthesis (Magalhães Filho et 
al. 2009), a common condition during the winter season. In general, low temperatures affect electron transport in thylakoids, the carbon reduction cycle, stomatal apparatus, carbohydrate metabolism, lipid peroxidation and water balance in plants (Allen and Ort 2001).

Photosynthesis requires an optimal balance between carbon fixation in the chloroplasts, sucrose synthesis in the cytosol and sucrose export to other plant organs, which is indirectly disrupted by low temperatures through the inhibition of plant growth. This inhibition decreases the recycling of inorganic phosphate between the cytosol and the chloroplast, causing low photosynthetic rates (Ensminger et al. 2006). The deleterious effects of low night temperature on photosynthesis may be observed during the following diurnal period, when there is high energetic pressure at the PSII (Allen et al. 2000, Allen and Ort 2001).

Injuries caused by cold temperatures are also associated with the generation of reactive oxygen species (ROS), which is a primary plant response to abiotic stresses and may cause oxidative damage (Mittler 2002). Oxidative stress induced by abiotic factors such as cold arises from a mismatch between ROS production and elimination rates by enzymatic and nonenzymatic antioxidant systems (Mittler 2002). Some plant species are grown on rootstocks that confer differential acclimation or tolerance to environmental stresses (Zhou et al. 2007), being the photosynthetic response affected in orange trees (Castle 2010, Machado et al. 2010).

Considering the available literature, the physiological mechanisms against cold damage in citrus plants would be rootstock-dependent. The Swingle citrumelo has been used extensively as a rootstock of citrus trees in cold regions (Castle 2010); however, the physiological traits related to cold tolerance are unknown. Our aim was to uncover the leaf physiological mechanisms affected by rootstock that improve the performance of citrus trees under cold conditions, hypothesizing that the sensitivity of photosynthesis to night chilling is rootstock-dependent and related to the activity of antioxidant systems.

\section{MATERIAL AND METHODS}

Plant material: We used Valencia orange trees [Citrus sinensis (L.) Osb.] grafted on two species of rootstock, Rangpur lime (Citrus limonia L.) and Swingle citrumelo (Citrus paradisi $x$ Poncirus trifoliata). The trees were six months old and planted in plastic bags with $5 \mathrm{~L}$ of substrate composed of $95 \%$ pine bark and 5\% vermiculite. Rangpur lime is the main rootstock in Brazil as it confers high crop yield and drought tolerance to citrus plants, whereas Swingle citrumelo rootstock is known to induce cold tolerance (Castle 2010).
Thermal treatment and growth conditions: Before thermal treatment, the plants were grown under greenhouse conditions and received daily irrigation and proper nutrients, as done by Magalhães Filho et al. (2009). Five days before the beginning of the experiment, the plants were transferred to a growth chamber (PGR14, Conviron, Canada): photoperiod of $12 \mathrm{~h}$, air temperature of $25 \pm 1 / 20 \pm 1^{\circ} \mathrm{C}$ (day/night), relative humidity of $65 \%$ and photosynthetic photon flux density (PPFD) of $800 \mu \mathrm{mol} \mathrm{m} \mathrm{m}^{-2} \mathrm{~s}^{-1}$. During this period, we did not verify significant differences in leaf gas exchange when comparing rootstocks. Thermal treatments began after the full acclimation to this environment, given by non-significant variation of midday photosynthesis between consecutive days. During the experiment, diurnal temperature remained constant and aboveground nocturnal temperatures varied. In each night, temperature was reduced to $8^{\circ} \mathrm{C}$ for $11 \mathrm{~h}$, and one hour before light period, the temperature was increased to $25 \pm 1{ }^{\circ} \mathrm{C}$ without changing any other environmental conditions. As the aim of this study was to evaluate only the nocturnal chilling, rewarming was done in darkness to prevent the illumination of plant tissues with different temperatures (Allen et al. 2000). After three nights of chilling, plants were recovered under nocturnal temperature of $20^{\circ} \mathrm{C}$ for two nights. Root system was protected by plastic bags and immersed in a container filled with water (Magalhães Filho et al. 2009) to maintain the root and substrate temperatures at $20 \pm 1^{\circ} \mathrm{C}$ throughout the experimental period. This process ensured that only the aerial plant portion was subjected to low night temperatures.

Leaf gas exchange and photochemistry: After the first $\left(20^{\circ} \mathrm{C}\right.$, control $)$, second and fourth $\left(8^{\circ} \mathrm{C}\right.$, chilling $)$, and sixth $\left(20^{\circ} \mathrm{C}\right)$ nights, we measured gas exchange and chlorophyll fluorescence with an infrared gas analyzer (Portable Photosynthesis System LI-6400, LI-COR, Lincoln, NE, USA) equipped with a fluorometer (6400-40, LI-COR). We measured the minimal $\left(F_{\mathrm{o}}\right)$ and maximum $\left(F_{\mathrm{m}}\right)$ fluorescence after 30 minutes of darkness, as well as the instantaneous fluorescence $\left(F^{\prime}\right)$ and maximum $\left(F_{\mathrm{m}}{ }^{\prime}\right)$ fluorescence in light-adapted leaves. The maximum variable fluorescence under dark and light conditions were calculated as $F_{\mathrm{v}}=F_{\mathrm{m}}-F_{\mathrm{o}}$ and $F_{\mathrm{v}}{ }^{\prime}=F_{\mathrm{m}}{ }^{\prime}-F_{\mathrm{o}}$, respectively. $F_{\mathrm{q}}$ ' was calculated as $F_{\mathrm{q}}{ }^{\prime}=F_{\mathrm{m}}{ }^{\prime}-F^{\prime}$ and represents the photochemical extinction of fluorescence caused by the oxidized centers of PSII (Baker 2008). These signals were used to calculate the maximum quantum efficiency of PSII photochemistry $\left(F_{\mathrm{v}} / F_{\mathrm{m}}\right)$, the PSII efficiency factor $\left(F_{\mathrm{q}}{ }^{\prime} / F_{\mathrm{v}}{ }^{\prime}\right)$, the operational efficiency of PSII $\left(F_{\mathrm{q}}{ }^{\prime} / F_{\mathrm{m}}{ }^{\prime}\right)$, and the nonphotochemical quenching $\left[N P Q=\left(F_{\mathrm{m}}-F_{\mathrm{m}}{ }^{\prime}\right) / F_{\mathrm{m}}{ }^{\prime}\right]$ (Baker 2008).

The leaf $\mathrm{CO}_{2}$ assimilation $\left(P_{\mathrm{n}}\right)$ and chlorophyll fluorescence response curves to the $\mathrm{CO}_{2}$ concentration in the chloroplast 
$\left(C_{c}\right)$ were measured simultaneously under the following conditions: PPFD of $1200 \mathrm{mmol} \mathrm{m}^{-2} \mathrm{~s}^{-1}$ (Machado et al. 2005), leafto-air vapor pressure deficit of $1.4 \pm 0.2 \mathrm{kPa}$, and leaf temperature of $25^{\circ} \mathrm{C}$. The intercellular $\mathrm{CO}_{2}$ concentration $\left(C_{\mathrm{i}}\right)$ and then $\mathrm{C}_{\mathrm{c}}$ were varied by changing the concentration of $\mathrm{CO}_{2}$ in the reference air, according to the procedure proposed by Long and Bernacchi (2003). The values of $C_{c}$ and the mesophyll conductance $\left(g_{i}\right)$ were estimated using the method described by Epron et al. (1995). The $P_{\mathrm{n}}$ responses to varying $C_{\mathrm{c}}$ were adjusted using the least squares method (Origin 7.5, OriginLab Corp., Northampton, MA, USA) with subsequent estimation of the maximum rate of ribulose-1,5-bisphosphate (RuBP) carboxylation $\left(V_{c, \max }\right)$ and the maximum electron transport rate driven RuBP regeneration $\left(J_{\max }\right)$, according to the model proposed by von Caemmerer (2000). The $\mathrm{CO}_{2}$ assimilation rate measured at air $\mathrm{CO}_{2}$ concentration of $1200 \mu \mathrm{mol} \mathrm{mol}^{-1}$ was considered the maximum $\mathrm{CO}_{2}$ assimilation $\left(P_{\text {nmax }}\right)$.

\section{Leaf water potential and plant hydraulic conduc-}

tivity: The leaf water potential was measured with a pressure chamber model 3005 (Soilmoisture Equipment Corp., Santa Barbara CA, USA $)$ at the pre-dawn $\left(\Psi_{\mathrm{WPD}}\right)$ and at 1:00 pm $\left(\Psi_{\mathrm{W} 13}\right)$. Measurements were taken at the same time in which leaf gas exchange was evaluated. As done previously (Ribeiro et al. 2009b), the plant hydraulic conductivity $\left(K_{\mathrm{L}}\right)$ was estimated as $K_{\mathrm{L}}=E_{13} /\left(\Psi_{\mathrm{WPD}}-\Psi_{\mathrm{W} 13}\right)$, where $E_{13}$ is the transpiration rate at 1:00 pm measured with the LI-6400 system.

\section{Leaf carbohydrates and antioxidant metabolism: Leaf} samples were collected around 1:00 pm for analysis of carbohydrates, lipid peroxidation (TBARS), ascorbate concentration and antioxidant activity. These samples were collected after the first night at $20^{\circ} \mathrm{C}$ (control, before cooling), after three nights at $8^{\circ} \mathrm{C}$ (cooling) and after the second night at $20^{\circ} \mathrm{C}$ (recovery from cooling). Samples were collected in the same plants evaluated for photosynthesis. We extracted the sucrose (SUC) and the total soluble sugars (SS) using a methanol:chloroform:water solution $(12: 5: 3 \mathrm{v} / \mathrm{v} / \mathrm{v})$, as described by Bieleski and Turner (1966). The SS and SUC concentrations were determined by the phenol-sulphuric method described by Dubois et al. (1956) and Handel (1968), respectively. The starch (STA) concentration was determined using the enzymatic method proposed by Amaral et al. (2007).

The hydrogen peroxide concentration was evaluated in fresh leaf samples $(0.1 \mathrm{~g})$ powdered in liquid nitrogen, following extraction with a $100 \mathrm{mM}$ potassium phosphate buffer ( $\mathrm{pH}$ 6.4) containing $5 \mathrm{mM} \mathrm{KCN}$, as specified by Cheeseman (2006). The reaction was carried out at $25^{\circ} \mathrm{C}$ for 30 minutes, and the absorbance was read at $560 \mathrm{~nm}$. The $\mathrm{H}_{2} \mathrm{O}_{2}$ concentration was calculated according to a standard curve and expressed as $\mathrm{mmol} \mathrm{g}^{-1}$ fresh mass (FM).

Lipid peroxidation was determined by measuring the thiobarbituric acid-reactive substances (TBARS). Samples of frozen leaves $(0.1 \mathrm{~g})$ were pulverized in liquid nitrogen and homogenized with $1 \mathrm{~cm}^{3}$ of $6 \%(\mathrm{w} / \mathrm{v})$ trichloroacetic acid (TCA) for 3 minutes. The homogenate was centrifuged at $12,000 \times \mathrm{g}$ for 15 minutes at $4^{\circ} \mathrm{C}$, and aliquots of $0.5 \mathrm{~mL}$ of the supernatant were mixed with $2 \mathrm{~mL}$ of $20 \%$ $(\mathrm{w} / \mathrm{v})$ TCA containing $0.5 \%(\mathrm{w} / \mathrm{v})$ tiobarbituric acid (TBA). The reaction was carried out at $95^{\circ} \mathrm{C}$ for $30 \mathrm{~min}$, and the absorbance was read at $532 \mathrm{~nm}$. The TBARS concentration was calculated using the molar extinction coefficient $\left(155 \mathrm{mM}^{-1} \mathrm{~cm}^{-1}\right)$ and expressed as nmol g-1 FM (Heath and Packer 1968).

The total ascorbate (AsA+DHA) concentration was determined by adding the leaf extract to a mixture of potassium phosphate buffer ( $\mathrm{pH} 7.4)$ containing $2 \mathrm{mM} \mathrm{DTT,} 0.5 \%(\mathrm{w} / \mathrm{v})$ N-ethylmaleimide, $10 \%(\mathrm{w} / \mathrm{v})$ TCA, $45 \%(\mathrm{w} / \mathrm{v}) \mathrm{H}_{2} \mathrm{PO}_{4}, 4 \%$ (w/v) bipyridyl, and 5\% (w/v) $\mathrm{FeCl}_{3}$. The reduced ascorbate (AsA) content was measured in the same medium of total ascorbate in absence of DTT and N-ethylmaleimide. The reaction was performed at $40^{\circ} \mathrm{C}$ for 30 minutes, and the absorbance was read at $525 \mathrm{~nm}$ according to the Kampfenkel, Montagu and Inzé (1995) method. The AsA+DHA and AsA contents were estimated using $\mathrm{L}$-ascorbate as a standard and expressed as $\mu \mathrm{mol}$ $\mathrm{g}^{-1} \mathrm{FM}$. The oxidized ascorbate (DHA) content was obtained by subtracting the reduced fraction (ASA) from the total content.

The superoxide dismutase (SOD; EC: 1.15.1.1) activity was determined by adding leaf extract to a mixture containing $50 \mathrm{mM}$ potassium phosphate buffer ( $\mathrm{pH} 7.8), 0.1 \mathrm{mM}$ EDTA, $13 \mathrm{mM}$ L-methionine, $2 \mu \mathrm{M}$ riboflavin, and $75 \mu \mathrm{M}$ p-nitro blue tetrazolium chloride (NBT) in the dark. The reaction was carried out under artificial illumination $(30 \mathrm{~W}$ fluorescent lamp) at $25^{\circ} \mathrm{C}$ for 6 minutes. The absorbance was measured at $540 \mathrm{~nm}$ (Giannopolotis and Ries 1977). One SOD activity unit (AU) was defined as the amount of enzyme required to inhibit 50\% of the NBT photoreduction (Beauchamp and Fridovich 1971), and the activity was expressed as $\mathrm{AU} \mathrm{g}^{-1} \mathrm{FM} \mathrm{min}^{-1}$.

The ascorbate peroxidase activity (APX; EC: 1.11.1.1) was assayed after the reaction of the extract in the presence of $50 \mathrm{mM}$ potassium phosphate buffer ( $\mathrm{pH} 6.0$ ) and $0.5 \mathrm{mM}$ ascorbic acid. The reaction began when $0.1 \mathrm{~mL}$ of $30 \mathrm{mM} \mathrm{H}_{2} \mathrm{O}_{2}$ was added, and the decreasing absorbance at $290 \mathrm{~nm}$ was monitored for 300 s (Nakano and Asada 1981).

The ascorbate peroxidase activity was estimated by utilizing the molar extinction coefficient of ascorbate $\left(2.8 \mathrm{mM}^{-1} \mathrm{~cm}^{-1}\right)$ and expressed as $\mu \mathrm{mol} \mathrm{ASA} \mathrm{g}^{-1} \mathrm{FM} \mathrm{min}^{-1}$. 
The catalase activity (CAT; EC: 1.11.1.6) was determined following the reaction of the extract in the presence of $50 \mathrm{mM}$ potassium phosphate buffer $(\mathrm{pH} 7.0)$ containing $20 \mathrm{mM} \mathrm{H}_{2} \mathrm{O}_{2}$. The reaction took place at $30^{\circ} \mathrm{C}$, with absorbance monitored at $240 \mathrm{~nm}$ for $300 \mathrm{~s}$ (Havir and McHale, 1987). The CAT activity was calculated according to the molar extinction coefficient of $\mathrm{H}_{2} \mathrm{O}_{2}\left(36 \mathrm{mM}^{-1} \mathrm{~cm}^{-1}\right)$ and is expressed as $\mathrm{mmol} \mathrm{H}_{2} \mathrm{O}_{2} \mathrm{~g}^{-1} \mathrm{FM} \mathrm{min}^{-1}$.

\section{Data analysis}

The experiment was arranged in a random block design with the rootstock as source of variation. The chilling effect was evaluated comparing the sampling times. The data were subjected to the analysis of variance (ANOVA) considering three (antioxidant system), five (photosynthesis) or six (carbohydrates) replications taken from different plants. When significant differences occurred, the mean values were compared using the Tukey test $(\mathrm{p}<0.05)$.

\section{RESULTS}

After the first cold night, $P_{n}$ decreased significantly $(\mathrm{p}<0.05)$ in orange trees grafted on both rootstocks (Figure 1A), but more markedly on Rangpur (-64\%) than on Swingle (-26\%). Following two additional cold nights, there was no variation in $P_{\mathrm{n}}$ values either on Rangpur or on Swingle rootstock. After the recovery at night temperature of $20^{\circ} \mathrm{C}, P_{n}$ of plants grafted on Rangpur did not return to the initial levels, whereas plants grafted on Swingle rootstock exhibited full recovery of $P_{n}$ (Figure 1A). $P_{n \max }$ was also inhibited $(\mathrm{p}<0.05)$ by $\sim 30 \%$ after one cold night on both rootstocks (Figure 1B). Following the night chilling, the $P_{\text {nmax }}$ response was clearly different between rootstocks, with plants on Swingle showing $P_{\text {nmax }}$ recovery during cold treatment, i.e., at the fourth day of night chilling. As found for $P_{n}$, plants grafted on Rangpur did not recover $P_{n \max }$ when night temperature returned to $20^{\circ} \mathrm{C}$. Night chilling decreased $g_{s}(\mathrm{p}<0.05)$ on both rootstocks (Figure 1C), with stomatal aperture being recovered only in plants grafted on Swingle after warm nights, i.e. $20^{\circ} \mathrm{C}$ (Figure $1 \mathrm{C}$ ). One cold night also reduced $g_{\mathrm{i}}(\mathrm{p}<0.05)$, with plants on both rootstocks showing recovery of the initial values after two warm nights (Figure 1D). There was no variation in $C_{i}$ of plants grafted on Rangpur due to night chilling, whereas there was an increasing trend of $C_{i}$ in plants grafted on Swingle (Figure 1E). Similar increasing trend was noticed for $C_{c}$ from the first cold night, regardless the rootstock (Figure $1 \mathrm{~F})$. Both $C_{\mathrm{i}}$ and $C_{\mathrm{c}}$ were always higher $(\mathrm{p}<0.05)$ in plants grafted on Rangpur as compared to Swingle (Figure 1E and F).
Considering the biochemistry of photosynthesis, $V_{c, \max }$ decreased in plants grafted on Rangpur rootstock after the first cold night $(\mathrm{p}<0.05)$, and the initial values were not recovered after returning night temperatures to $20^{\circ} \mathrm{C}$ (Figure $1 \mathrm{G}$ ). On the other hand, plants grafted on Swingle exhibited a small reduction $(\sim 11 \%)$ in $V_{c, \text { max }}$ throughout the experiment (Figure 1G). After the first cold night, there was a significant decrease $(\mathrm{p}<0.05)$ in $J_{\max }$ on both rootstocks; however, only plants grafted on Swingle recovered $J_{\max }$ (Figure 1H). In general, $V_{c, \max }$ and $J_{\max }$ were higher in plants on Swingle than on Rangpur rootstock $(\mathrm{p}<0.05)$.

The leaf water potential was not affected by night chilling; however, $K_{L}$ did decrease (Table 1 ). Only plants grafted on Swingle did exhibit recovery of $K_{\mathrm{L}}$ after returning night temperature to $20^{\circ} \mathrm{C}$ (Table 1). At this time, $K_{\mathrm{L}}$ on Swingle was 1.4-times higher than on Rangpur rootstock.

Regarding the photochemistry, $F_{v} / F_{m}$ did not vary due to cold night in plants grafted on Swingle $(p>0.05)$ and it was always higher on Swingle than on Rangpur (Figure 2A). Gradual and significant decreases in $F_{\mathrm{v}} / F_{\mathrm{m}}, F_{\mathrm{q}}{ }^{\prime} / F_{\mathrm{v}}$ ' and $F_{\mathrm{q}}{ }^{\prime} / F_{\mathrm{m}}$ ' due to cold treatment were found only in plants grafted on Rangpur lime (Figures 2A-C). Plants grafted on Swingle rootstock exhibited consistently higher $F_{\mathrm{q}}{ }^{\prime} / F_{\mathrm{m}}$ ' and $F_{\mathrm{q}}{ }^{\prime} / F_{\mathrm{v}}$ ' than those ones on Rangpur rootstock $(\mathrm{p}<0.05)$, regardless of cold treatment (Figures $2 \mathrm{~B}$ and $\mathrm{C}$ ). Night chilling caused significant increases $(\mathrm{p}<0.05)$ in NPQ of plants grafted on both rootstocks (Figure 2D). At the end of chilling treatment and also during the recovery time, plants grafted on Rangpur presented the highest NPQvalues $(\mathrm{p}<0.05)$.

The leaf concentrations of SS and SUC were not affected by night chilling, regardless the rootstocks (Table 2). Curiously, the lowest SS and SUC concentrations were noticed at the recovery time in plants grafted on Rangpur lime. Plants grafted on Swingle also presented the lowest SUC concentration at the recovery time. Low night temperature increased STA concentration only in plants grafted on Rangpur lime, while plants grafted on Swingle presented an increasing trend of STA throughout the experimental period (Table 2).

The concentration of TBARS was not affected by cold night in plants grafted on Rangpur, whereas plants on Swingle showed a slight reduction of TBARS (Table 2). Only plants grafted on Rangpur have increased $\mathrm{H}_{2} \mathrm{O}_{2}$ concentrations due to night chilling (Table 2). However, leaf $\mathrm{H}_{2} \mathrm{O}_{2}$ concentrations after night chilling were similar on both rootstocks ( $c$. $9.7 \mu \mathrm{mol} \mathrm{g}{ }^{-1} \mathrm{FM}$ ). In general, the recovery time was sufficient to reduce the leaf $\mathrm{H}_{2} \mathrm{O}_{2}$ concentration to the initial levels. The SOD activity increased due to cold night, with this response being greater in plants grafted on Rangpur (Table 2). After the recovery time, 


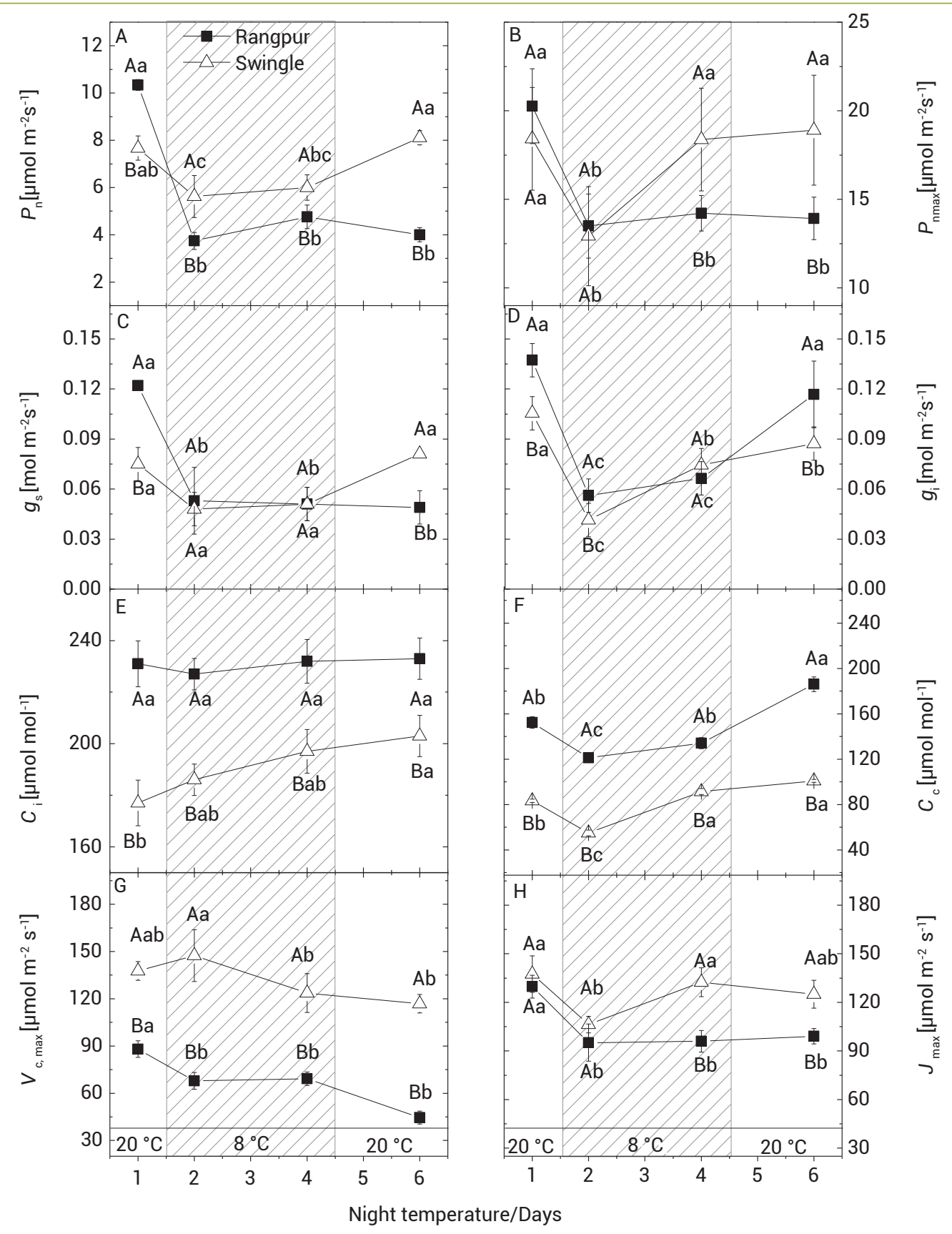

Figure 1. Leaf $\mathrm{CO}_{2}$ assimilation $\left(P_{\mathrm{n}^{\prime}}\right.$ in $\left.\mathrm{A}\right)$; stomatal conductance $\left(g_{\mathrm{s}^{\prime}}\right.$ in $\left.\mathrm{C}\right)$; intercellular $\mathrm{CO}_{2}$ concentration $\left(C_{\mathrm{i}}\right.$, in $\left.\mathrm{E}\right)$; maximum carboxylation efficiency $\left(V_{c m a x}\right.$ in $\left.\mathrm{G}\right)$; leaf maximum $\mathrm{CO}_{2}$ assimilation at $1,200 \mu \mathrm{mol} \mathrm{CO} \mathrm{mol}^{-1}\left(P{ }^{2}\right.$, in B); internal conductance $\left(g_{\mathrm{i}}\right.$; in $\left.\mathrm{D}\right)$; $\mathrm{CO}_{2}$ concentration inside the chloroplast $\left(C_{c^{\prime}}\right.$ in $\left.F\right)$ and maximum electron transport $\left(J_{\text {max }}\right.$ in $\left.\mathrm{H}\right)$ as affected by night temperature in Valencia sweet orange plants grafted on Rangpur lime or Swingle citrumelo. The first day $=$ control $\left(20^{\circ} \mathrm{C}\right)$, the second and fourth days $=$ night chilling $\left(8^{\circ} \mathrm{C}\right.$, dashed area) and the sixth day $=$ two days after returning the temperature to $20^{\circ} \mathrm{C}$ (recovery). Measurements taken under PPFD of $1,200 \mu \mathrm{mol} \mathrm{m} \mathrm{m}^{-2} \mathrm{~s}^{-1}$ and $25^{\circ} \mathrm{C}$. Mean $\pm \mathrm{SE}(\mathrm{n}=5)$.

SOD activity was marginally reduced on Rangpur, but not on Swingle (Table 2). APX activity increased due to cold night and it remained high after the recovery period, regardless the rootstocks (Table 2). As SOD and APX, CAT activity increased due to night chilling, with plants grafted on
Swingle exhibiting the highest cold sensitivity (Table 2). After the recovery period, CAT activity returned to its initial values in plants grafted on Rangpur whereas it presented a large inhibition ( $50 \%)$ on Swingle. Low night temperature did not cause important changes in the concentration 
Table 1. Changes in leaf water potential at pre-dawn $\left(\Psi_{\text {WPD }}[\mathrm{MPa}]\right)$ and afternoon $\left(\Psi_{\mathrm{w} 13}[\mathrm{MPa}]\right)$ and plant hydraulic conductivity $\left(K_{\mathrm{L}}\right.$ $\left[\mathrm{mmol} \mathrm{m}^{-2} \mathrm{~s}^{-1} \mathrm{MPa}^{-1}\right]$ ) as affected by night temperature in Valencia sweet orange trees grafted on Rangpur lime or Swingle citrumelo

\begin{tabular}{llllllc} 
& \multicolumn{2}{c}{ Initial $\left(20^{\circ} \mathrm{C}\right)$} & \multicolumn{2}{c}{ Cold $\left(8^{\circ} \mathrm{C}\right)$} & \multicolumn{2}{c}{ Recovery $\left(20^{\circ} \mathrm{C}\right)$} \\
\cline { 2 - 6 } Variable* & Rangpur & Swingle & Rangpur & Swingle & Rangpur \\
$\Psi_{\text {WPD }}$ & $-0.33^{\mathrm{Aa}}$ & $-0.37^{\mathrm{Aa}}$ & $-0.22^{\mathrm{Aa}}$ & $-0.27^{\mathrm{Aa}}$ & $-0.37^{\mathrm{Aa}}$ & $-0.45^{\mathrm{Aa}}$ \\
\hline$\Psi_{\mathrm{W} 13}$ & $-0.80^{\mathrm{Aa}}$ & $-0.75^{\mathrm{Aa}}$ & $-0.85^{\mathrm{Aa}}$ & $-0.90^{\mathrm{Aa}}$ & $-0.78^{\mathrm{Aa}}$ & $-0.92^{\mathrm{Aa}}$ \\
$K_{\mathrm{L}}$ & $4.72^{\mathrm{Aa}}$ & $3.54^{\mathrm{Ba}}$ & $1.64^{\mathrm{Ab}}$ & $1.65^{\mathrm{Ab}}$ & $2.35^{\mathrm{Bb}}$ & $3.37^{\mathrm{Aa}}$ \\
\hline
\end{tabular}

Different capital letters indicate statistical differences $(p<0.05$, Tukey) between rootstocks for the same evaluation day, whereas lowercase letters represent differences between evaluations for the same rootstock ( $p<0.05$, Tukey). Mean values of five replications.

Initial $\left(20^{\circ} \mathrm{C}\right)=$ control, Cold $\left(8^{\circ} \mathrm{C}\right)=$ after the fourth night at $8^{\circ} \mathrm{C}$, and Recovery $\left(20^{\circ} \mathrm{C}\right)=$ two days after returning the night temperature to $20^{\circ} \mathrm{C}$

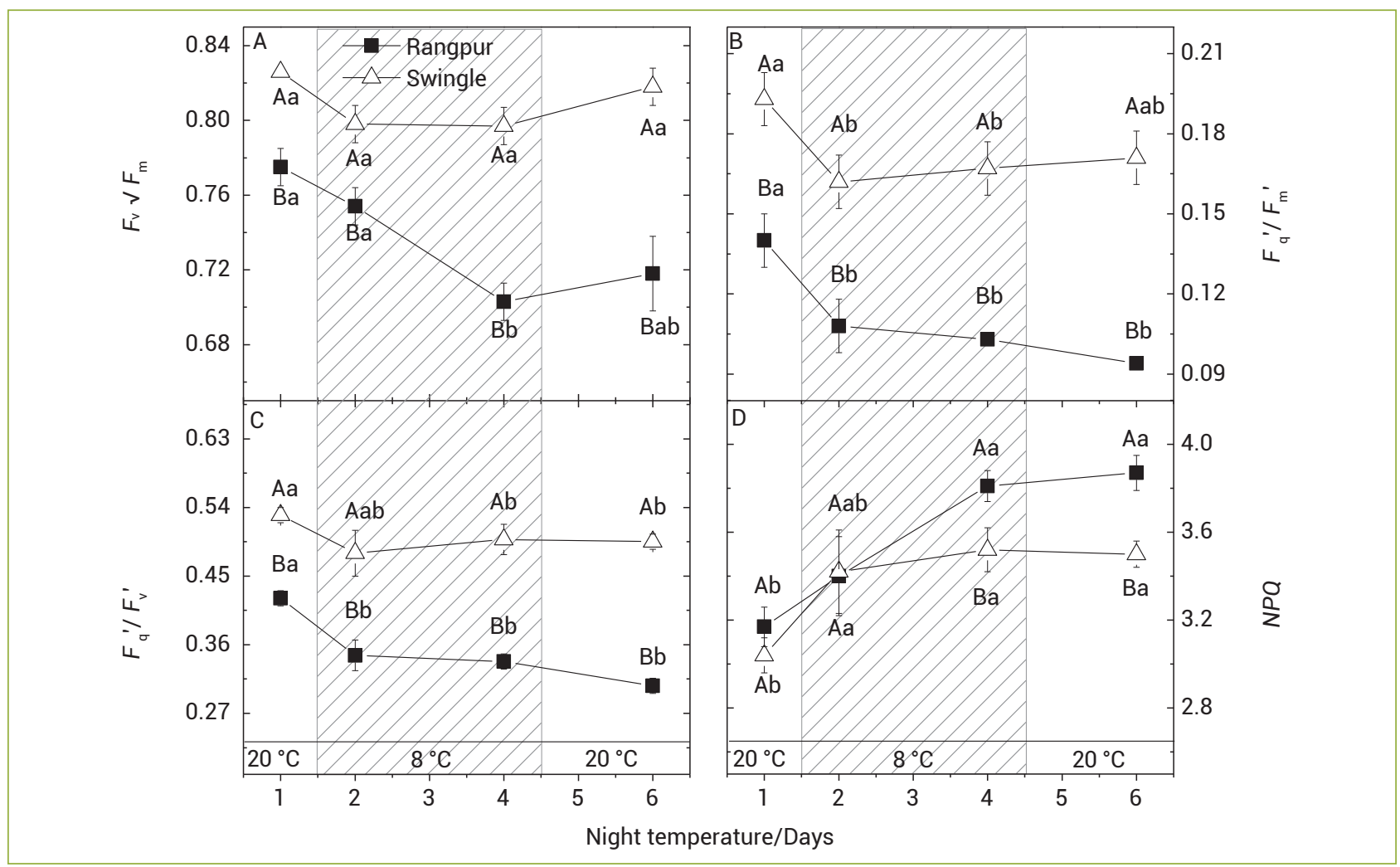

Figure 2. Changes in maximum quantum efficiency of PSII $\left(F_{v} / F_{m}\right.$, in A), PSII efficiency factor $\left(F_{q}^{\prime} / F_{m}{ }^{\prime}\right.$, in B), PSII operating efficiency $\left(F_{\mathrm{q}}{ }^{\prime} / F_{\mathrm{v}}{ }^{\prime}\right.$, in $\left.\mathrm{C}\right)$, and nonphotochemical quenching $(N P Q$, in $\mathrm{D})$ due to night temperature in Valencia sweet orange grafted on Rangpur lime or Swingle citrumelo. The first day $=$ control $\left(20^{\circ} \mathrm{C}\right)$, the second and fourth days $=$ night chilling $\left(8^{\circ} \mathrm{C}\right.$, dashed area) and the sixth day $=$ two days after returning the temperature to $20^{\circ} \mathrm{C}$ (recovery). Measurements taken under PPFD of $1,200 \mu \mathrm{mol} \mathrm{m}^{-2} \mathrm{~s}^{-1}$ and $25^{\circ} \mathrm{C}$.

of both oxidized and reduced forms of ascorbate in leaves of both rootstocks (Table 2 ).

\section{DISCUSSION}

\section{Photosynthetic responses to low night temperature} are rootstock-dependent: The rootstocks caused significant changes in photosynthetic responses to low night temperature. In orange trees grafted on Rangpur, $P_{n}$ and $g_{s}$ decreased when exposed to night chilling and did not return to their initial values after two days of recovery under warmer conditions, revealing an irreversible damage. On the other hand, plants grafted on Swingle rootstock recovered their initial $P_{n}$ and $g_{s}$ values after the low night treatment (Figures $1 \mathrm{~A}$ and $\mathrm{C}$ ). It is known that reductions in $P_{n}$ are indirectly associated to low $g_{s}$ and $g_{i}$, which would decrease $C_{i}$ and $C_{c}$ in stressed plants. However, this response was not observed herein. As chilled-plants exhibited reductions in $V_{c, \max }$ and $J_{\max }$ (Figures $1 \mathrm{G}$ and $\mathrm{H}$ ), $C_{\mathrm{i}}$ and $\mathrm{C}_{\mathrm{c}}$ values remained nearly constant or even increased throughout the experimental period (Figures $1 \mathrm{E}$ and $\mathrm{F}$ ). 
Table 2. Changes in concentrations of soluble sugars [ $\mathrm{mg} \mathrm{g}^{-1}$, sucrose [ $\mathrm{mg} \mathrm{g}^{-1}$, starch [ $\mathrm{mg} \mathrm{g}^{-1}$, thiobarbituric acid-reactive substances (TBARS, [nmol MDA-TBA g-1 FM]), hydrogen peroxide $\left(\mathrm{H}_{2} \mathrm{O}_{2},\left[\mu \mathrm{mol} \mathrm{g}^{-1} \mathrm{FM}\right]\right)$, in the activities of superoxide dismutase (SOD [UA mg ${ }^{-1}$ Prot. $\left.\mathrm{min}^{-1}\right]$ ), ascorbate peroxidase (APX [umol AsA mg ${ }^{-1}$ Prot. $\left.\mathrm{min}^{-1}\right]$ ), catalase (CAT [ $\left.\mu \mathrm{mol} \mathrm{H}_{2} \mathrm{O}_{2} \mathrm{~g}^{-1} \mathrm{FM} \mathrm{min} \mathrm{m}^{-1}\right]$ ), and in concentrations of oxidized (DHA [ $\left.\mu \mathrm{mol} \mathrm{g}^{-1} \mathrm{FM}\right]$ ) and reduced (AsA [ $\left.\mu \mathrm{mol} \mathrm{g}^{-1} \mathrm{FM}\right]$ ) ascorbate due to night temperature in Valencia sweet orange plants grafted on Rangpur lime or Swingle citrumelo

\begin{tabular}{|c|c|c|c|c|c|c|}
\hline \multirow{2}{*}{ Variables* } & \multicolumn{2}{|c|}{ Initial $\left(20^{\circ} \mathrm{C}\right)$} & \multicolumn{2}{|c|}{ Cold $\left(8^{\circ} \mathrm{C}\right)$} & \multicolumn{2}{|c|}{ Recovery $\left(20^{\circ} \mathrm{C}\right)$} \\
\hline & Rangpur & Swingle & Rangpur & Swingle & Rangpur & Swingle \\
\hline Soluble sugars & $68.1^{\mathrm{Aa}}$ & $73.1^{\mathrm{Aa}}$ & $60.6^{\mathrm{Aa}}$ & $65.4^{\text {Aa }}$ & $46.0^{\mathrm{Bb}}$ & $66.7^{\text {Аa }}$ \\
\hline Sucrose & $42.0^{\mathrm{Aa}}$ & $34.3^{\text {Aab }}$ & $32.2^{\mathrm{Aa}}$ & $37.8^{\mathrm{Aa}}$ & $19.9^{\mathrm{Ab}}$ & $23.8^{\mathrm{Ab}}$ \\
\hline Starch & $81.5^{\mathrm{Ab}}$ & $54.5^{\mathrm{Ab}}$ & $164.2^{\mathrm{Aa}}$ & 72. $7^{\text {Bab }}$ & $108.0^{\mathrm{Ab}}$ & $94.2^{\mathrm{Aa}}$ \\
\hline TBARS & $81.1^{\mathrm{Ba}}$ & $88.8^{\mathrm{Aa}}$ & $80.3^{\mathrm{Aa}}$ & $69.1^{\mathrm{Bc}}$ & $63.6^{\mathrm{Bb}}$ & $79.3^{\mathrm{Ab}}$ \\
\hline $\mathrm{H}_{2} \mathrm{O}_{2}$ & $8.66^{\mathrm{Bb}}$ & $9.57^{\text {Aa }}$ & $9.74^{\mathrm{Aa}}$ & $9.70^{\mathrm{Aa}}$ & $8.97^{\mathrm{Ab}}$ & $8.34^{\mathrm{Ab}}$ \\
\hline SOD & $1.15^{\mathrm{Bc}}$ & $1.87^{\mathrm{Ab}}$ & $2.64^{\mathrm{Aa}}$ & $2.32^{\mathrm{Ba}}$ & $2.41^{\mathrm{Ab}}$ & $2.31^{\mathrm{Aa}}$ \\
\hline APX & $0.53^{\mathrm{BC}}$ & $0.61^{\mathrm{Ac}}$ & $0.96^{\mathrm{Ab}}$ & $0.92^{\mathrm{Ab}}$ & $1.03^{\mathrm{Aa}}$ & $1.01^{\mathrm{Aa}}$ \\
\hline CAT & $33.9^{\mathrm{Ab}}$ & $29.4^{\mathrm{Bb}}$ & $37.8^{\mathrm{Aa}}$ & $38.7^{\mathrm{Aa}}$ & $30.5^{\mathrm{AC}}$ & $20.6^{\mathrm{BC}}$ \\
\hline DHA & $13.12^{\mathrm{Aa}}$ & $10.11^{\mathrm{Bb}}$ & $14.46^{\mathrm{Aa}}$ & $11.13^{\mathrm{Bab}}$ & $13.51^{\mathrm{Aa}}$ & $12.20^{\text {Aa }}$ \\
\hline AsA & $2.81^{\mathrm{Ba}}$ & $3.02^{\mathrm{Aa}}$ & $2.83^{\mathrm{Aa}}$ & $2.86^{\mathrm{Ab}}$ & $2.57^{\mathrm{Bb}}$ & $2.85^{\mathrm{Ab}}$ \\
\hline
\end{tabular}

Different capital letters indicate statistical differences ( $<<0.05$, Tukey) between rootstocks for the same evaluation day, whereas lowercase letters represent differences between evaluations for the same rootstock $(\mathrm{p}<0.05$, Tukey). Mean values of six replication for carbohydrates or three replications for antioxidant system. Initial $\left(20^{\circ} \mathrm{C}\right)=$ control, Cold $\left(8^{\circ} \mathrm{C}\right)=$ after the fourth night at $8^{\circ} \mathrm{C}$, and Recovery $\left(20^{\circ} \mathrm{C}\right)=$ two days after returning the night temperature to $20^{\circ} \mathrm{C}$

The reduction in $g_{s}$ can be related to the plant hydraulic properties (Flexas et al. 1999), as suggested by $K_{\mathrm{L}}$ (Table 1 ). Reductions in $K_{\mathrm{L}}$ were caused by chilling injuries in aboveground structures such as decreased protoplasm permeability (Sellin and Kupper 2007). In addition, increases in resistance to water flow inside plant body are also due to increased water viscosity caused by low temperatures. The recovery of $K_{\mathrm{L}}$ after chilling exposure when comparing plants grafted on Rangpur and Swingle rootstocks was also associated to the differences in $g_{s}$. In fact, stomatal aperture was recovered only in plants grafted on Swingle rootstock (Figure 1C).

Considering the mesophyll, we know that $g_{\mathrm{i}}$ is regulated by aquaporins and affected by temperature (Bernacchi et al. 2002, Flexas et al. 2006). The effects of low night temperature on $g_{\mathrm{i}}$ were relatively more deleterious to plants grafted on Rangpur rootstock, with plants grafted on Swingle exhibiting partial recovery of $g_{\text {i }}$ during the night chilling (Figure $1 F$ ). We believe that the rapid $P_{n}$ recovery on Swingle rootstock was related to the rapid recovery of $\mathrm{CO}_{2}$ diffusion through the stomata and mesophyll. This assumption is also based on the dynamics of $P_{n \max }$ (Figure 1B). While the inhibition of $P_{n}$ was not reversed under $\mathrm{CO}_{2}$ saturation in plants grafted on Rangpur, it was in plants grafted on Swingle.

Photosynthesis was limited by metabolic factors and this kind of limitation (low $J_{\max }$ and $V_{c, \max }$ ) was more severe and persistent in plants grafted on Rangpur rootstock (Figures $1 \mathrm{G}$ and $\mathrm{H}$ ). On Swingle rootstock, $J_{\max }$ decreased after the first cold night and presented full recovery during the cold treatment (Figure 1H). Considering the carboxylation reactions, decreases in $V_{c, \text { max }}$ due to cold night have been attributed to low Rubisco activity and concentration (Allen et al. 2000, Allen and Ort 2001, Zhou et al. 2004, Bertamini et al. 2005, 2007). Zhou et al. (2007) observed that cold-sensitive species exhibited reduction in cytokinin level, which could partially explain the decrease in $V_{c, \max }$ observed. Low cytokinins levels may reduce mRNA related to the synthesis of photosynthetic enzymes such as Rubisco and fructose-1,6-bisphosphatase (Davis and Zhang, 1991), and also those related to the RuBP regeneration (Zhou et al. 2007, Strauss and Heerden 2011).

Regarding the photochemistry, the decrease in $F_{\mathrm{v}} / F_{\mathrm{m}}$ was due to a significant reduction in $F_{m}$ (data not shown) that only occurred on Rangpur rootstock (Figure 2A) and could be attributed to decreases in the turnover of D1 protein in PSII complexes (Bertamini et al. 2007). As $F_{v} / F_{m}$ was not affected by low night temperature in plants grafted on Swingle, we may argue that photoprotective mechanisms involving increased $N P Q$ and decreased $F_{\mathrm{q}}{ }^{\prime} / F_{\mathrm{m}}$ ' were efficient in preventing excessive energy pressure at PSII (Figure 2).

Starch is the main leaf carbohydrate affected by low night temperature: The main effect of cold night on leaf carbohydrate status was noticed in starch concentration, especially in plants grafted on Rangpur that presented almost two-times higher concentrations as 
compared to the initial condition (Table 2). This increase may be a consequence of (i) inhibition of starch hydrolases due to the low temperature (Leegood and Edward, 1996) or (ii) reduction in sink demand due to growth impairment (Iglesias et al. 2002, Ribeiro et al. 2012). In fact, citrus growth is inhibited at temperatures below $13^{\circ} \mathrm{C}$ (Reuther, 1973), and it is known that the decreased demand for carbohydrates can also down-regulate citrus photosynthesis (Iglesias et al. 2002, Ribeiro et al. 2012). After two nights of exposure to $20^{\circ} \mathrm{C}$ (recovery), the starch concentration in leaves of plants grafted on Rangpur returned to its initial value (Table 2). We may argue that high night temperature likely stimulated starch remobilization and plant growth. However, SS and SUC did not accompany the starch increase and the lowest values reported in plants grafted on Rangpur are probably caused by low $P_{n}$ (Figure 1A) and increased sink demand (i.e. regrowth).

\section{Controlling the potential oxidative damage caused by low night temperature: Regarding the antioxidant} responses, we noticed that SOD, APX and CAT activities on both rootstocks exhibited similar response to low night temperature (Table 2). In general, the stimulation of SOD, APX and CAT activities by low night temperature may have contributed to the protection of chloroplasts and peroxisomes by eliminating excess superoxide and $\mathrm{H}_{2} \mathrm{O}_{2}$ radicals and preventing oxidative damage generated by the imbalance between the photochemical and biochemical phases of $\mathrm{CO}_{2}$ assimilation (Mittler 2002, Dai et al. 2009). An appropriate balance between gene expression and the activities of SOD and APX isoforms is essential to prevent oxidative damage, with SOD and APX functioning in a coordinated manner to impede the

\section{REFERENCES}

Allen DJ, Ratner K, Giller YE, Gussakovsky EE, Shahak Y, Ort DR (2000) An overnight chill induces a delayed inhibition of photosynthesis at midday in mango (Manguifera indica L.). Journal of Experimental Botany 51:1893-1902.

Allen DJ, Ort DR (2001) Impacts of chilling temperatures on photosynthesis in warm climate plants. Trends in Plant Science 6:36-42.

Amaral LIV, Gaspar M, Costa PMF, Aidar MPM, Buckeridge MS (2007) A new rapid and sensitive enzymatic method for extraction and quantification of starch in plant material. Hoehnea 34:425-431.

Baker NR (2008) Chlorophyll fluorescence: a probe of photosynthesis in vivo. Annual Review of Plant Biology 59:89-11. accumulation of reactive oxygen species under stressful conditions (Mittler 2002). Our results indicate that the ascorbate redox system was not an important element in plant protection under our experimental conditions. This result was expected as the enzymatic system was shown to be extremely effective and non-enzymatic protection is more active under acute stress conditions when enzymatic reactions fail in system detoxification (Mittler 2002). Accordingly, plants grafted on both rootstocks did not present symptoms of oxidative stress induced by the cold treatment, as given by marginal and reversible increases in TBARS and $\mathrm{H}_{2} \mathrm{O}_{2}$ concentrations (Table 2).

Concluding, the sensitivity of citrus trees to low night temperature is affected by rootstocks. Plant performance under cold stress was improved when plants were grafted on Swingle rootstock and such positive acclimation was based on cold-tolerance and recovery capacity of photosynthetic metabolism. The antioxidant system was not affected by rootstocks and it was effective in protecting citrus plants against the potential damage caused by low temperature. Our findings indicate that plant physiological performance can be significantly improved under stressful conditions by managing the combination scion-rootstock in tree species.

\section{ACKNOWLEDGEMENTS}

To the National Council for Scientific and Technological Development (CNPq, Brazil) for the fellowships granted to ECM, RVR and JAGS. This research (Proc. 05/57862-8) and the scholarships granted to DFSPM and JRMF (Proc. 06/59382-6 and 07/53520-0) were funded by the São Paulo Research Foundation (FAPESP, Brazil).

Beauchamp C, Fridovich I (1971) Superoxide dismutase: Improved assay applicable to acrylamide gels. Analytical Biochemistry 44:276-287.

Bernacchi CJ, Portis AR, Nakano H, von Caemmerer S, Long SP (2002) Temperature response of mesophyll conductance. Implications for the determination of Rubisco enzyme kinetics and for limitations to photosynthesis in vivo. Plant Physiology 130:1992-1998.

Bertamini M, Muthuchelian K, Rubinigg M, Zorer R, Nedunchezhian $\mathrm{N}$ (2005) Low night temperature (LNT) induces changes of photosynthesis in grapevine (Vitis vinifera L.) plants. Plant Physiology and Biochemistry 43:693-699.

Bertamini M, Zulini L, Muthuchelian K, Nedunchezhian N (2007) Low night temperature effects on photosynthetic 
performance on two grapevine genotypes. Biologia Plantarum 51:381-385.

Bieleski RL, Turner A (1966) Separation and estimation of amino acids in crude plant extracts by thin-layer electrophoresis and chromatography. Analytical Biochemistry 17:278-293.

Caemmerer S von (2000) Biochemical models of leaf photosynthesis. CSIRO Publishing, Victoria.

Castle WS (2010) A career perspective on citrus rootstocks, their development, and commercialization. Hortscience 45:11-15.

Cheeseman JM (2006) Hydrogen peroxide concentrations in leaves under natural conditions. Journal of Experimental Botany 57:2435-2444.

Dai F, Huang Y, Zhou M, Zhang G (2009) The influence of cold acclimation on antioxidative enzymes and antioxidants in sensitive and tolerant barley cultivars. Biologia Plantarum 53:257-262

Davis W, Zhang J (1991) Root signals and regulation of growth and development of plants in drying soil. Annual Review of Plant Physiology 42:55-76.

Dubois M, Gilles KA, Hamilton JK, Rebers PA, Smith F (1956) Colorimetric method for determination of sugars and related substances. Analytical Chemistry 28:350-356.

Ensminger I, Busch F, Huner NPA (2006) Photostasis and cold acclimation: sensing low temperature through photosynthesis. Physiologia Plantarum 126:28-44.

Epron D, Godard D, Cornic G, Genty B (1995) Limitation of net $\mathrm{CO}_{2}$ assimilation rate by internal resistances to $\mathrm{CO}_{2}$ transfer in the leaves of two tree species (Fagus sylvatica L. and Castanea sativa Mill.). Plant, Cell and Environment 18:43-51.

Flexas J, Badger M, Chow WS, Medrano H, Osmond CB (1999) Analysis of the relative increase in photosynthetic $\mathrm{O}_{2}$ uptake when photosynthesis in grapevine leaves is inhibited following low night temperatures and/or water stress. Plant Physiology 121:675-684.

Flexas J, Ribas-Carbo M, Bota J, Galmes J, Henkle M, MartinezCanellas S, Medrano H (2006) Decreased Rubisco activity during water stress is not induced by decreased relative water content but related to conditions of low stomatal conductance and chloroplast $\mathrm{CO}_{2}$ concentration. New Phytologist 172:73-82.

Giannopolotis CN, Ries SK (1977) Superoxide dismutases: I. Occurrence in higher plants. Plant Physiology 59:309-314.

Handel E (1968). Direct microdetermination of sucrose. Analytical Biochemistry 22:280-283.

Havir EA, McHale NA (1987) Biochemical and development characterization of multiples forms of catalase in tobaccoleaves. Plant Physiology 84:450-455.

Heath RL, Packer L (1968) Photoperoxidation in isolated chloroplasts. I. Kinetics and stoichiometry of fatty acid peroxidation. Archives of Biochemistry and Biophysics 125:189-198.

Iglesias DJ, Lliso I, Tadeo FR, Talon M (2002) Regulation of photosynthesis through source-sink imbalance in citrus is mediated by carbohydrate content in leaves. Physiologia Plantarum 116:563-572.

Kampfenkel K, Montagu MV, Inzé R (1995) Extraction and determination of ascorbate and dehydroascorbate from plant tissue. Analytical Biochemistry 225:165-167.

Leegood RC, Edwards EG (1996) Carbon metabolism and photorespiration: temperature dependence in relation to other environmental factors. In: Baker NR (Ed.) Photosynthesis and the environment, pp.191-221. Kluwer Academic, London.

Long SP, Bernacchi CJ (2003) Gas exchange measurements, what can they tell us about the underlying limitations to photosynthesis? Procedures and sources of error. Journal of Experimental Botany 54:2393-2401.

Machado DFSP, Machado EC, Machado RS, Ribeiro RV (2010) Effects of low night temperature and rootstocks on diurnal variation of leaf gas exchange rates and photochemical activity of 'Valência' sweet orange plants. Revista Brasileira de Fruticultura 32:351-359.

Machado EC, Medina CL, Gomes MMA, Habermann G (2002) Seasonal variation of photosynthetic rates, stomatal conductance and leaf water potential in 'Valência' orange trees. Scientia Agricola 59:53-58.

Machado EC, Schmidt PT, Medina CL, Ribeiro RV (2005) Photosynthetic responses of three citrus species to environmental factors. Pesquisa Agropecuária Brasileira 40:1161-1170.

Magalhães Filho JR, Machado EC, Machado DFSP, Ramos RA, Ribeiro RV (2009) Root temperature variation and photosynthesis of 'Valencia' sweet orange nursery trees. Pesquisa Agropecuária Brasileira 44:1118-1126.

Mittler R (2002) Oxidative stress, antioxidants, and stress tolerance. Trends in Plant Science 7:405-410.

Nakano Y, Asada K (1981) Hydrogen peroxide is scavenged by ascorbate-especific peroxidase in spinach chloroplasts. Plant and Cell Physiology 22:1068-1072.

Reuther W (1973) Climate and citrus behavior. In: Reuther W (Ed.) The Citrus industry, v.3, pp.280-337. University of California, Riverside.

Ribeiro RV, Machado EC (2007) Some aspects of citrus ecophysiology in subtropical climates: re-visiting photosynthesis under natural conditions. Brazilian Journal of Plant Physiology 19:393-411.

Ribeiro RV, Machado EC, Santos MG, Oliveira, RF (2009a) Photosynthesis and water relations of well-watered orange plants as affected by winter and summer conditions. Photosynthetica 47:215-222.

Ribeiro RV, Machado EC, Santos MG, Oliveira RF (2009b) Seasonal and diurnal changes in photosynthetic limitation of young sweet orange trees. Environmental and Experimental Botany 66:203-211.

Ribeiro RV, Machado EC, Habermann G, Santos MG, Oliveira, RF (2012) Seasonal effects on the relationship between 
photosynthesis and leaf carbohydrates in orange trees. Functional Plant Biology 39:471-480.

Sellin A, Kupper P (2007) Temperature, light and leaf hydraulic conductance of little-leaf linden (Tilia cordata) in a mixed forest canopy. Tree Physiology 27:679-688.

Strauss AJ, Heerden PDR van (2011) Effects on both the roots and shoots of soybean during dark chilling determine the nature and extent of photosynthesis inhibition. Environmental and Experimental Botany 74:261-271.
Zhou YH, Yu JQ, Huang LF, Nogués S (2004) The relationship between $\mathrm{CO}_{2}$ assimilation, photosynthetic electron transport and water-water cycle in chill exposed cucumber leaves under low light and subsequent recovery. Plant, Cell and Environment 27:1503-1514.

Zhou YH, Huang L, Zhang Y, Shi K, Yu J, Nogués S (2007) Chill-induced decrease in capacity of RuBP carboxylation and associated $\mathrm{H}_{2} \mathrm{O}_{2}$ accumulation in cucumber leaves are alleviated by grafting onto figleaf gourd. Annals of Botany 100:839-848. 